\title{
Kesinoniman Kata dalam Bahasa Muna Dialek Madongka Kecamatan Lakudo Kabupaten Buton Tengah
}

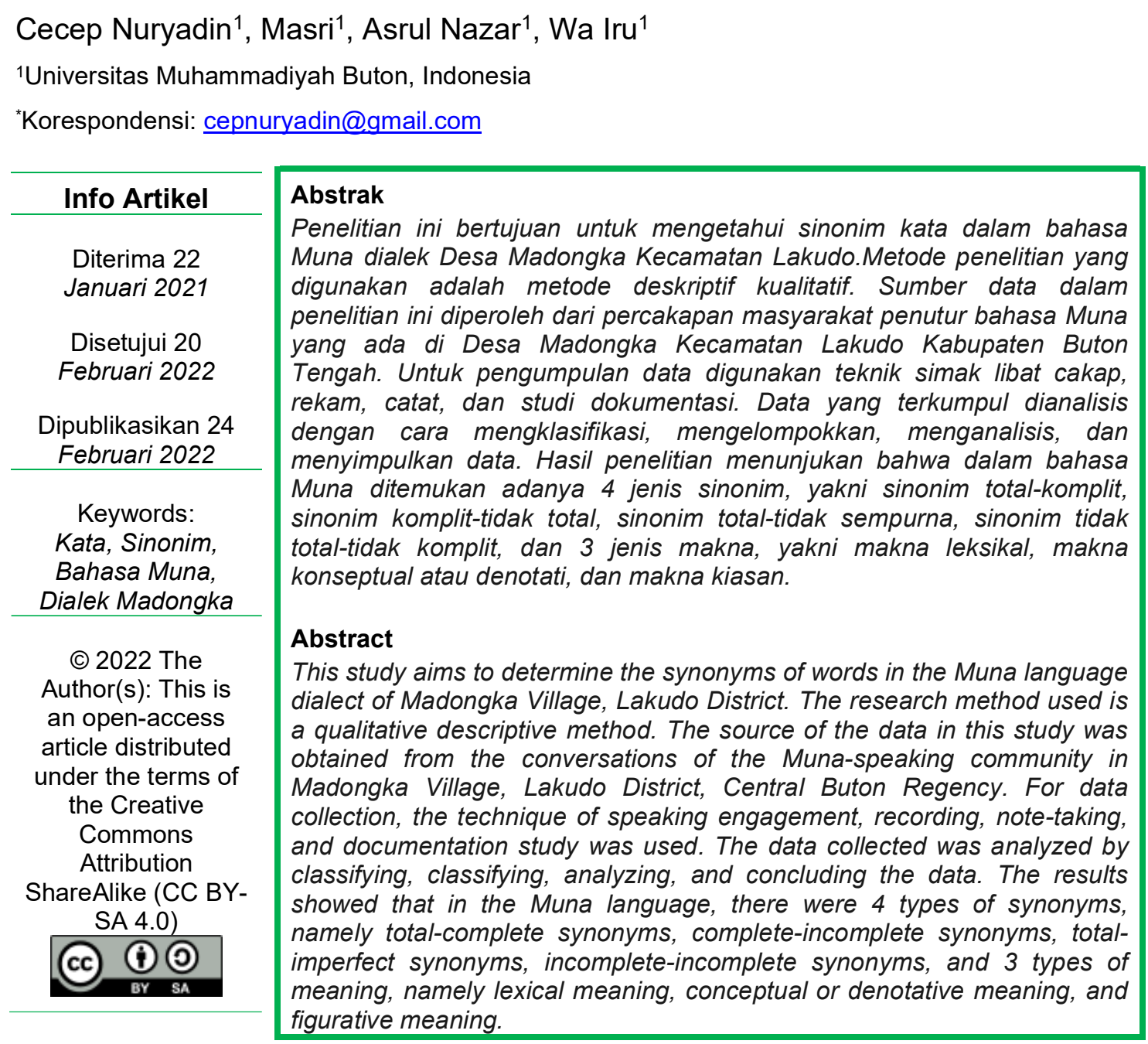

\section{Pendahuluan}

Manusia sebagai makhluk sosial yang menggunakan bahasa dalam berkomunikasi. Bahasa adalah sistem lambang yang berwujud bunyi atau bunyi ujar. Lambang bunyi adalah suatu pengertian, suatu konsep, suatu ide, atau suatu pikiran yang ingin disampaikan dalam wujud bunyi itu (Kridalaksana dalam Resmini, 2010). Lambang-lambang itu mengacu pada sesuatu konsep, ide, atau pikiran, maka dapat dikatakan bahwa bahasa itu mempunyai makna. Lambanglambang bunyi bahasa yang bermakna itu di dalam bahasa berupa satuan-satuan bahasa yang berwujud morfem, kata, frase, klausa, kalimat, dan wacana. Semua 
satuan tersebut mempunyai makna. Dengan demikian, bahasa memiliki fungsi yaitu sebagai media dalam penyampaian informasi berisi gagasan, pemikiran, dan hasrat yang digunakan masyarakat untuk beromunikasi yang berperan dalam berbagai aspek kehidupan manusia.

Bahasa mempunyai fungsi sebagai alat komunikasi dalam berinteraksi, bahasa dapat dikaji melalui dua cara yaitu secara internal maupun eksternal. Kajian secara internal adalah pengkajian yang dilakukan hanya pada intern bahasanya saja seperti fonologi (bunyi), morfologi (bentuk), sintaksis (susunan kalimat), dan semantik (makna) (Tahir, dkk., 2021). Sedangkan secara eksternal adalah pengkajian yang dilakukan terhadapat struktur yang berada di luar bahasa tersebut misalnya sosiolinguistik, psikolinguistik, neurolinguistik,dan lain-lain. Kontak bahasa merupakan fenomena kebahasaan, seperti pemertahanan bahasa, pergeseran bahasa alih kode, campur kode, interferensi diglosia, konvergensi dan kedwibahasaan (Agustin dan Chaer dalam Sholihah, 2018)

Dwibahasawan sering disebut juga sebagai seorang pengguna bahasa yang lebih dari satu bahasa begitu pun dengan budayanya seorang dwibahasawan pasti mengerti dan memahami beberapa budaya. Akibat dari kedwibahasaan maka muncul adanya alih kode can campur kode sehingga penggunaan bahasanya menjadi tumpang tindih. Alih kode dan campur kode sering digunakan oleh kalangan masyarakat yang menguasai lebih dari satu bahasa.

Bahasa Muna merupakan salah satu wujud identitas masyarakat Muna. Bahasa Muna ini juga memiliki kekhasan dan variasi seperti bahasa-bahasa yang lain, baik dalam hal pelafalan, intonasi, kosakata, pola kalimat, maupun tata bahasanya. Variasi tersebut antara lain; (i) fonem / q /, / y /, dan / z / tidak ditemukan dalam bahasa daerah Muna; (ii) kata yang mengandung makna lebih dari satu atau ganda, misalnya /sala/ yang artinya /jalan/ atau /celana/ bahkan sekarang kata /sala/ juga diartikan /salah/, (iii) kata-kata yang mengandung arti sama atau mirip, misalnya /tei/ artinya /simpan/ dan /runsa/ artinya /simpan/. Selain itu, ada juga kata yang memiliki makna berlawanan.

Kata yang mengandung arti yang sama atau mirip disebut sinonim. Harimurti dalam Pateda (2009:168) mengemukakan "Sinonim adalah bentuk bahasa yang maknanya mirip atau sama dengan bentuk lain, kesamaan itu berlaku bagi kata atau kalimat". Meskipun sinonim merupakan kata yang memiliki makna sama atau mirip, namun dalam penggunaanya tidak sama. Misalnya kata meninggal dan mati.

Suku Muna memiliki bahasa daerah yakni bahasa Muna. Bahasa Muna digunakan oleh masyarakat Muna dalam berkomunikasi. Sehubungan dengan itu Pateda dalam Marafat, (2017) mengatakan "bahasa daerah adalah bahasa yang dipakai oleh penutur bahasa yang tinggal di daerah tersebut untuk berkomunikasi antarsesama mereka". Dalam bahasa Muna terdapat banyak kosakata yang bersinonim atau memiliki kesamaan arti, misalnya: gampi dan sowo. Keduanya bermakna tinggalkan. Akan tetapi kata sowo akan berubah maknanya jika digunakan pada kalimat yang sama. Misalnya dalam kalimat, "Wa Ani nogampigho lambuno = Ani meninggalkan rumahnya" berbeda maknanya dengan "Wa Ani nosowogho lambuno = Ani melarikan rumahnya". Dalam bahasa Muna kata sowo seharusnya tidak pantas digunakan dalam kalimat yang ditujukan kepada sesama manusia, melainkan kepada hewan atau yang bernuansa alam gaib seperti mengusir roh jahat. Kata bersinonim tersebut jika tidak dipahami maka akan keliru 
jika digunakan dalam kalimat, dan sumber terjadinya kesalahpahaman antarsesama. Oleh sebab itu, peneliti ingin mengatahui bagaimanakah masyarakat Muna dapat membedakan kata yang memiliki makna yang sama atau mirip dalam penggunaannya?

Masyarakat Muna khusunya generasi muda kurang memahami penggunaan kata yang bersinonim. Misalnya, kata 'fuma' digunakan untuk teman sebaya atau yang lebih muda. Namun, terkadang kata tersebut digunakan untuk yang lebih tua sehingga menyebabkan kesan yang tidak baik atau tidak sopan. Misalnya dalam kalimat, "Ina mai dofumagho diki = Ibu sini kita makan dulu", kalimat tersebut merupakan kalimat yang dianggap tidak sopan, seharusnya "Ina maimo dotangkahigho diki = lbu marilah kita makan dulu". Hal ini disebabkan kurangnya pemahaman terhadap makna kata sehingga menyebabkan kerancuan atau kesalahpahaman dalam berinteraksi. Selain itu, kurangnya referensi yang membahas kata-kata yang bersinonim secara lengkap dan mendalam.

Misalnya sinonim kata noghae memiliki makna konseptual yang sama dan saling bertukar dalam konteks kalimat, contoh: (Kalimat 1) Aita kambanuku ghane noghae kanau welo daoa (saya malu kalau sampai dia menangis dalam pasar), (Kalimat 2) aita kambanuku ghane nekahulei kanau welo (saya malu kalau sampai dia menangis dalam pasar) kedua kata ini hanya dibedakan oleh keras kecilnya suara yang dikeluarkan, kata naoghae biasanya menangis dengan suara pelan atau kecil, sedangkan naekahulei biasanya menangis dengan suara keras. Meskipun ada perbedaan pada kedua kata tersebut namun bisa saling mengganti dalam semua konteks kalimat, misalnya kata meninggal dan mati. Sinonim adalah bentuk bahasa yang maknanya mirip atau sama dengan bentuk lain, kesamaan itu berlaku bagi kata atau kalimat. Meskipun sinonim merupakan kata yang memiliki makna sama atau mirip, namun dalam penggunaanya tidak sama.

\section{Metode Penelitian}

Pemilihan metode dalam penelitian sangatlah penting maka dari itu peneliti memilih motode deskriftif kualitatif dalam melakukan penelitian. (Zaim, 2014) menuturkan bahwa untuk memahami makna dari peristiwa-peristiwa dan interaksi-interaksi manusia dalam situasi tertentu perlu adanya perspektif fenologis atau cerminan dari metode kualitatif.

Maka dari itu, peneliti kualitatif harus mengungkap pandangan atau pendapat subjek penelitiannya secara akurat, selain itu, peneliti harus cermat dalam memperhatikan informasi yang disampaikan oleh informan. Oleh Karena itu, peneliti harus benar-benar memberikan informasi dari segala fenomena yang ditemukan di lapangan.

Data dalam penelitian ini terdiri atas data primer dan data sekunder. Data primer adalah kata yang mengandung sinonim yang diperoleh secara langsung dari hasil wawancara lapangan. Data sekunder adalah data yang diperoleh dari penutur masyarakat Desa Madongka Kecamatan Lakudo.

Teknik yang digunakan dalam mengumpulkan data yaitu teknik, simak libat cakap (SLC), Teknik rekam, teknik catat, dan teknik domkumentasi.

Dalam menganalisis data hasil penelitian ini maka harus menggunakan dua metode analisis data yaitu metode distribusional atau metode agih dan metode padan atau metode identita. 
Mahsun (2012: 93) menyatakan bahwa metode distribusional ini dikembangkan oleh ahli linguistik struktural Amerika seperti Bloomfield, Nida, Hockett, dan Harris. Berbeda dengan metode padan yang dalam analisisnya menggunakan alat penentu di luar bahasa, metode distribusional menggunakan alat penentu di dalam bahasa itu sendiri. Metode distribusional menganalisis bahasa berdasarkan prilaku satuan lingual bahasa yang diteliti. Dengan demikian analisisnya memberikan keabsahan secara linguistik.

Langkah-langkah Metode distribusional adalah sebagai berikut:

a) Mendengarkan informan berbahasa Muna yang berada di Desa Madongka Kecamatan Lakudo yang dijadikan sebagai objek penelitian.

b) Mengidentifikasi bagian-bagian bahasa Muna yang berada di Desa Madongka Kecamatan Lakudo yang terdapat pada jenis-jenis sinonim dan makna sinonim.

c) Mengidentifikasikan setiap data yang sesuai dengan tujuan penelitian.

d) Mendeskripsikan (menggambarkan) data-data yang telah diklasifikasi.

e) Menyeleksi data sesuai dengan tujuan yang telah ditetapkan sebagai hasil penelitian.

Sedangkan metode padan, sering juga disebut metode identitas (identity method), adalah suatu metode yang dipakai untuk menentukan identitas satuan bahasa tertentu dengan menggunakan alat penentu di luar bahasa yang bersangkutan. Dengan kata lain metode padan ini alat penentunya terlepas dan tidak menjadi bagian dari bahasa yang diteliti.

Table 1. Alat Penentu Metode Padan

\begin{tabular}{clll}
\hline & Alat penentu & & Nama Metode \\
\hline 1. & Referen & 1. & Referensial \\
\hline 2. & Organ wicara & 2. & Fonetis Artikulatoris \\
\hline 3. & Langue lain & 3. & Translasional \\
\hline 4. & Tulisan & 4. & Ortografis \\
\hline 5. & Mitra wicara & 5. & Pragmatis \\
\hline
\end{tabular}

\section{Hasil}

Pemerolehan data hasil penelitian ini meliputi jenis sinonim dan makna sinonim dalam Bahasa Muna dialek Madongka. Pengambilan (perekaman) data dilakukan selama 4 kali dan ditambah dengan data dari penutur asli bahasa Muna dialek Madongka. Dari hasil analisis data, diperoleh jenis-jenis dan makna sinonim Bahasa Muna dialek Madongka, yang diuraikan sebagai berikut:

\subsection{Jenis-Jenis Sinonim dalam Bahasa Muna dialek Madongka}

Sinonim dalam Bahasa Muna dialek Madongka terdiri atas 4 jenis. Keempat jenis sinonim itu diuraikan berikut ini.

\section{a. Sinonim Total-Komplit}

Sinonim total-komplit yakni memiliki ciri makna asosiatif dan konseptual yang sama dan saling bertukar dalam semua konteks. Berdasarkan data percakapan (lihat lampiran data sinonim) ditemukan sinonim total-komplit dalam Bahasa Muna dialek Madongka yang diuraikan pada tabel 1 berikut: 
Tabel 2. Sinonim Total-Komplit

\begin{tabular}{|c|c|c|c|}
\hline $\begin{array}{l}\text { No } \\
\text {. }\end{array}$ & $\begin{array}{c}\text { Sinonim } \\
\text { Total- } \\
\text { Komplit }\end{array}$ & Contoh Kalimat & Deskripsi \\
\hline 1. & $\begin{array}{l}\text { Asumandu = } \\
\text { asumiki 'saya } \\
\text { sendokkan' }\end{array}$ & $\begin{array}{l}\text { 1. Mai owa pirimu barangka, } \\
\text { asumandu angkoemu } \\
\text { hintum labhino waita (kalau } \\
\text { begitu kalian bawa saja } \\
\text { piring akan saya } \\
\text { sendokkan sisanya tadi } \\
\text { untuk kalian) } \\
\text { 2. Mai owa pirimu barangka, } \\
\text { asumiliki angkoemu hintum } \\
\text { labhino waita (kalau begitu } \\
\text { kalian bawa saja piring } \\
\text { akan saya sendokkan } \\
\text { sisanya tadi untuk kalian) }\end{array}$ & $\begin{array}{l}\text { Kata asumandu pada kalimat } 1 \\
\text { bersinonim total-komplit dengan } \\
\text { asumiki pada kalimat } 2 \text {. Dikatakan } \\
\text { bersinonim total-komplit karena } \\
\text { kedua kata ini memiliki identitas } \\
\text { makna konseptual yang sama dan } \\
\text { saling bertukar dalam konteks } \\
\text { kalimat yang sama, kedua kata ini } \\
\text { hanya dibedakan oleh jenis } \\
\text { makanan yang akan disendok, } \\
\text { asumiki berarti akan menyendok } \\
\text { makanan berkuah, sedangkan } \\
\text { asumiki berarti akan menyendok } \\
\text { makanan yang tidak berkuah. } \\
\text { Meskipun ada perbedaan } \\
\text { pada kedua kata tersebut namun } \\
\text { bisa ma mengganti dalam } \\
\text { saling ment semua } \\
\text { konteks kalimat. }\end{array}$ \\
\hline 2. & $\begin{array}{l}\text { Bheta = } \\
\text { kawawe } \\
\text { 'sarung' }\end{array}$ & $\begin{array}{l}\text { 1. Korohanomu mahingga } \\
\text { mina } \\
\text { Daepake bhaju tadepakem } \\
\text { kawu bheta (dulu biarpun } \\
\text { tidak pake baju yang } \\
\text { penting pake sarung) } \\
\text { 2. Korohanomu mahingga } \\
\text { mina } \\
\text { Daepake bhaju tadepakem } \\
\text { kawu bheta (dulu biarpun } \\
\text { tidak pake baju yang } \\
\text { penting pake sarung) }\end{array}$ & $\begin{array}{l}\text { Kata bheta pada kalimat } 1 \\
\text { bersinonim total-komplit dengan } \\
\text { kawawe pada kalimat } 2 \text {. Dikatakan } \\
\text { bersinonim total-komplit karena } \\
\text { kedua kata ini memiliki identitas } \\
\text { makna konseptual yang sama dan } \\
\text { saling bertukar dalam konteks } \\
\text { kalimat yang sama, yang } \\
\text { membedakan kedua kata ini hanya } \\
\text { terlihat pada ciri dari bentuk sarung } \\
\text { tersebut, 'bheta' biasanya } \\
\text { berbentuk kain panjang yang } \\
\text { kedua ujungnya tersambung, } \\
\text { sedangkan 'kawawe' bentuknya } \\
\text { kedua ujung kain tidak } \\
\text { tersambung. Meskipun ada } \\
\text { perbedaan pada kedua kata } \\
\text { tersebut namun bisa saling } \\
\text { mengganti dalam } \\
\text { semua konteks kalimat. }\end{array}$ \\
\hline
\end{tabular}

Data pada tabel 2, menunjukkan bahwa dalam Bahasa Muna dialek Madongka terdapat jenis sinonim total-komplet.

\section{b. Sinonim Komplit-Tidak Total}

Sinonim komplit-tidak total yakni memiliki identitas makna konseptual dan asosiatif yang sama tetapi tidak dapat saling mengganti dalam konteks kalimat yang sama. Berdasarkan data percakapan (lihat lampiran data sinonim) ditemukan 
sinonim total-komplit dalam Bahasa Muna dialek Madongka yang diuraikan pada tabel 2 berikut.

Tabel 3. Sinonim komplit-tidak total

\section{Sinonim \\ No Komplit-Tidak Total}

1. Nobhari

$=$ nedhampu

'banyak'
Contoh dalam Kalimat

1. Nobhari tora kamoala Wa Taota indewi (banyak lagi hasil penjualan Wa Taota kemarin.

2. Welokamaraku nedhampu siakito (di dalam kamarku banyak semut)
2. Kabisaraghomu 1. Ohae kabisaraghomu$$
=
$$

kapogauhamu

= mewamba-

wamba

'yang kamu bicarakan'

nagha bhela (apa

yang kamu bicarakan

itu?)

2. Pedahae

kapogaughomu indewi bhe Wa Ani, nohunda? (bagaimana yang

kamu bicarakan

dengan Wa Ani, dia

mau?)

3. Omamaragho hae

gara sampe

omewamba- wamba

peda waitu? (apa yang

membuat kamu marah

sampai kamu banyak

bicara seperti tadi?)
Kata nobhari pada kalimat 1 bersinonim komplit-tidak total dengan nedhampu dengan kalimat 2. Dikatakan bersinonim komplit-tidak total karena kedua kata ini memiliki identitas makna konseptual yang sama namun tidak bisa saling bertukar dalam konteks kalimat yang sama, yang membedakan kedua kata ini yaitu pada pemakaian kata tersebut, nobhari pemakaian katanya lebih halus, sedangkan kata nedhampu pemakaian katanya kasar dan hanya di khususkan pada penyebutan hewan, dengan perbedaan pemakaian kata tersebut sehingga tidak bisa saling mengganti dalam konteks kalimat yang sama.

Kata kabisaraghomu pada kalimat 1 bersinonim komplit- tidak total dengan kapogauhamu pada kalimat 2 dan mewamba-wamba pada kalimat 3 . Dikatakan bersinonim komplit-tidak total karena ketiga kata ini memiliki identitas makna konseptual yang sama namun tidak bisa saling bertukar dalam konteks kalimat yang sama, perbedaannya dapat dilihat pada pemakaian kata-kata tersebut dalam contoh kalimat di samping. 
3. Kansa-kansalo = noporawu 'campur'

4. Noopuli nopadae 'habis'

5. Meghompano $=1$. metengkino $=$ mebhatendeno 'yang melempar'
1. Ingka andoa tado kansa-kansalomo kune adonanno (kalau mereka tinggal di campur-campurkan adonannya)

2. Mamano mieno Wuna maka noporawu bhe Bogisino (mamanya orang Muna tapi campur dengan bugisnya)

1. Oinae kune Noopuli opadaem hintum obhantoloem ojambu ita (astaga itu jambu sudah habis kalian makan?)

2. Nopadae kawu nekabaerano dosa doi ainia (uang ini hanya habis/ludes dibayarkan hutang)

\section{Miehi molowuno} meghompano ghato morondo waita (orang-orang mabuk yang melempar di atas atap tadi malam)

2. Anahi awatu metengkino tiang listrik tano kandindim (anak sana yang melempari tiang listrik sampai bunyi- bunyi)

3. Mebhatendeno kaghaci indewi waitu gara dofogajie (yang lempar layang-layang Kemarin ternyata digaji)

6. Munta nangku= 1. Mina nati dofum jambu 'kunyah' (jambu ini dikunyah dimakan) munta ainia tidak kalau

2. Bunga tewiseno lambu dopadae nonangkue sapi (bunga di depan rumah habis dikunyah/ dimakan sapi)
Kata kansa-kansalo pada kalimat 1 bersinonim komplit- tidak total dengan noporawu pada kalimat 2. Dikatakan bersinonim komplit-tidak total karena kedua kata ini memiliki identitas makna konseptual yang sama namun tidak bisa saling bertukar dalam konteks kalimat yang sama, perbedaannya dapat dilihat pada pemakaian kata-kata tersebut dalam contoh kalimat di samping.

Kata tanowolom pada kalimat 1 bersinonim komplit-tidak total dengan tanokawum pada kalimat 2. Dikatakan bersinonim komplit-tidak total karena kedua kata ini memiliki identitas makna konseptual yang sama namun tidak bisa saling bertukar dalam konteks kalimat yang sama, perbedaannya dapat dilihat pada pemakaian kata-kata tersebut dalam contoh kalimat di samping.

Kata meghompano pada kalimat 1 bersinonim komplit-tidak total dengan metengkino pada kalimat 2 dan mebhatendeno pada kalimat 3 . Dikatakan bersinonim komplit-tidak total karena ketiga kata ini memiliki identitas makna konseptual yang sama namun tidak bisa saling bertukar dalam konteks kalimat yang sama, perbedaan pada ketiga kata ini dapat dilihat pada pemakaian kata- kata tersebut dalam contoh kalimat di samping.

Kata munta pada kalimat 1 bersinonim komplit-tidak total dengan nangku pada kalimat 2. Dikatakan sinonim komplittidak total karena kedua kata ini memiliki identitas makna konseptual yang sama namun tidak bisa saling bertukar dalam konteks kalimat yang sama, perbedaan pada kedua kata ini pada pemakaian kata-kata tersebut, munta pemakaiannya lebih halus, sedangkan nangku pemakaiannya lebih kasar. 
7. Kambanuku = 1. Aita kambanuku dua Kata kambanuku pada kalimat 1 kakaililiku 'saya ghane naoghae malu'

kanau welo daoa (saya juga malu kalau sampai dia menangis dalam pasar)

2. Akaili-ili ane akumala we pesta maka paepake bhaju bughou (saya malu ke pesta kalau tidak pake baju baru) bersinonim komplit-tidak total dengan

kakailili pada kalimat 2. Dikatakan sinonim komplit- tidak total karena kedua kata ini memiliki identitas makna konseptual yang sama namun tidak bisa saling bertukar dalam konteks kalimat yang sama, yang membedakan kedua kata ini pada makna kata-kata tersebut, kambanuku berarti seseorang yang merasa sangat malu, sedangkan akaili-ili artinya seseorang yang malu hanya karena tidak percaya diri.

Data pada tabel 3 di atas menunjukkan bahwa dalam Bahasa Muna dialek Madongka terdapat jenis sinonim komplit-tidak total.

\section{c. Sinonim Total-Tidak Sempurna}

Sinonim total-tidak sempurna yakni tidak memiliki identitas makna konseptual dan asosiatif yang sama tetapi bisa saling mengganti dalam konteks kalimat yang lain. Penggunaan kata yang mengandung sinonim didapat secara langsung dari lingkungan, data yang diambil dari penutur masyarakat Desa Madongka Kecamatan Lakudo. Berdasarkan data percakapan (lihat lampiran data sinonim) ditemukan sinonim total-tidak sempurna dalam Bahasa Muna dialek Madongka yang disajikan pada tabel 3 sebagai berikut:

Tabel 4. Sinonim total-tidak sempurna

\section{Sinonim \\ No Total-Tidak Sempurna \\ Contoh dalam Kalimat}

1. Nopogaa

= noporunsa

'berpisah'

1. Nodo korondoha lagi mina nahumunda nopogaa bhe dotno susunoa inia (kalau dia tidur malam tidak bisah pisah dengan dot susunya)

2. Nodo korondoha lagi mina nahumunda noporunsa bhe dotno susunoa inia (kalau dia tidur malam tidak bisah Pisah dengan dot susunya)

2. Nokantabhar 1. Nokantabharo kaodono o gara hadae kaoheru = hanomu (berarti karena nodh ai

2. Nodhai kaodono gara terganggu tidurnya sehingga dia cengeng) hadae kaoheru hanomu' (berarti karena Terganggu tidurnya

\section{Deskripsi}

Kata nopogaa pada kalimat 1 bersinonim total-tidak sempurna dengan doporunsa pada kalimat 2 . Dikatakan sinonim total-tidak sempurna karena kedua kata ini tidak memiliki makna asositif yang sama, namun bisa saling bertukar dalam konteks kalimat yang sama.

Kata nokantabharo pada kalimat 1 bersinonim total-tidak sempurna dengan nodhai pada kalimat 2 . Dikatakan sinonim total-tidak sempurna karena kedua kata ini tidak memiliki makna asositif yang sama, namun bisa saling bertukar dalam konteks kalimat yang sama. 
sehingga dia cengeng)

3. Ohunda 1. Ohunda dua hintua

Kata ohunda pada kalimat 1 bersinonim total-tidak sempurna dengan opindalo opindalo mau jambu? Atau kamu 'kamu juga ingin jambu?)

$\mathrm{m}$ 2. Opindalo dua hintua au dhambu? (kamu juga atau mau jambu? Atau kamu u kam juga ingin jambu?) pada kalimat 2. Dikatakan sinonim total-tidak sempurna karena kedua kata ini tidak memiliki makna asositif yang sama, namun bisa saling bertukar dalam konteks kalimat yang ingin'

4. Tulugi $=1$. Bhara kune anoa hadae nobhari tulugie

lalami 'bantu'

2. Bhara kune anoa hadae nobharidulumie (mungkin karena banyak yang bantu dia)

5. Sabutu = koalaha 'terpaksa'

1. Sabutu kaasi atawatawarianemu (terpaksa kasian saya mulai tawarkan)

2. Koalaha kaasi atawatawarianemu dua (terpaksa kasian saya mulai tawarkan)

sama.

Kata tulumi pada kalimat 1 bersinonim total-tidak sempurna dengan lalami pada kalimat 2. Dikatakan sinonim totaltidak sempurna karena kedua kata ini tidak memiliki makna asositif yang sama, namun bisa saling bertukar dalam konteks kalimat yang sama.

Kata sabutu pada kalimat 1 bersinonim komplit-tidak total dengan koalaha pada kalimat 2. Dikatakan sinonim total-tidak sempurna karena kedua kata ini tidak memiliki makna asositif yang sama, namun bisa saling bertukar dalam konteks kalimat yang sama.

Kata kaposuleha pada kalimat 1 bersinonim total-tidak komplit dengan kapololiha pada kalimat

2. Dikatakan sinonim total-tidak sempurna karena kedua kata ini tidak memiliki makna asositif yang sama, namun bisa saling bertukar dalam konteks kalimat yang sama.

2. Paingka kaerabuhano

tora nembali

kapololihano (itulah sebabnya dia buat satu lagi supaya bisa saling bergantian)

7. Datumeiem 1. Datumeiem netoples $=$ barangka kue ainia (kita darumunsae m 'kita simpan, kita taruh' taruh saja di toples kue yang ini atau kita simpan saja di toples kue yang ini)

2. darumunsaem netoples barangka (kita taruh saja di toples kue yang ini atau kita simpan saja di toples kue yang ini)

Kata datumeieam pada kalimat 1 bersinonim total-tidak komplit dengan darumunsaem pada kalimat 2. Dikatakan sinonim total-tidak sempurna karena kedua kata ini tidak memiliki makna asositif yang sama, namun bisa saling bertukar dalam konteks kalimat yang sama. 
8. Kohula $=1$. Nando kohula maka hadae 'kayanya, sepertiny a' kadadano roghoenu tapi sayur daun licin, (sepertinya masih ada atau kayanya masih ada tapi sayur daun licin)

2. Nando hadae maka kadadano roghoenu (sepertinya masih ada tapi sayur daun licin, atau kayanya masih ada tapi sayur daun licin)
Kata kohula pada kalimat 1 bersinonim total-tidak komplit dengan hadae pada kalimat 2. Dikatakan sinonim total-tidak sempurna karena kedua kata ini tidak memiliki makna asositif yang sama, namun bisa saling bertukar dalam konteks kalimat yang sama.

Data pada tabel 4 di atas menunjukkan bahwa dalam Bahasa Muna dialek Madongka terdapat jenis sinonim total-tidak sempurna.

\section{d. Sinonim Tidak Total-Tidak Komplit}

Sinonim tidak total-tidak komplit yakni tidak memiliki identitas makna konseptual dan asosiatif yang sama dan tidak bisa saling mengganti dalam konteks kalimat yang sama. Berdasarkan data percakapan (lihat lampiran data sinonim) ditemukan sinonim tidak total-tidak komplit dalam Bahasa Muna dialek Madongka yang diuraikan pada tabel 4 sebagai berikut:

Tabel 5. Sinonim tidak total-tidak komplit

No.

Sinonim

Tidak Total-

Tidak

Komplit

1.

Dopoghonughonui = dopokapo-kapoi 'berkumpul'

2. Mieno lambuno = tungguno kareteno 'suami, penjaga'
Contoh dalam Kalimat

1. Dadihanomu omie dopoghonu- ghonui we kaparasohano (akhirnya orang berkumpul di tempat jualannya)

2. Kapipihindo dopokapo-kapoi welo panino inando (anak ayam ini berkumpul di dalam sayap induknya)

1. Deparaso kawu bhe mieno lambuno (hanya berjualan dengan suaminya)

2. Nandom bhara tungguno kareteno we lambu awatu? (kira-kira sudah ada penjaganya di rumah sana?)

\section{Deskripsi}

Kata dopoghonu-ghonui pada kalimat 1 bersinonim tidak komplit-tidak total dengan dopokapo-kapoi pada

kalimat 2. Dikatakan sinonim tidak total-tidak komplit karena kedua kata ini selain tidak memiliki makna asosiatif yang sama juga tidak dapat saling mengganti dalam konteks kalimat yang sama. Untuk lebih jelasnya dapat dilihat pada contoh kalimat di samping

Kata mieno lambu pada kalimat 1 bersinonim tidak komplit-tidak total dengan tungguno kareteno pada kalimat 2. Dikatakan sinonim tidak total-tidak komplit karena kedua kata ini selain tidak memiliki makna asosiatif yang sama juga tidak dapat saling mengganti dalam konteks kalimat yang sama. Untuk lebih jelasnya dapat dilihat pada contoh kalimat di samping. 
3. Karunggahino = kariano 'ribut sekali, ramai sekali'
1. Karunggahino anahihi kune telambu tata, (ribut sekali anak-anak di rumah)

2. Kariano acara we tida (ramai sekali acara di perbatasan)

4. Delongkolongko = delodolodo 'tidurtiduran'

5. Feiilndoi diundo $=$ rabundo 'perilaku, kelakuan'

1. Rampahano minaho daekulia dadihanomu delodo-lodo kansuru we kosndo (karena belum kuliah jadi mereka tidurtiduran terus di kos)

2. Bhekando wawa (kucing-kucing sana tidur-tiduran di bawah kolong rumah)

1. Pata

kapoasahando rampano

nopandehaanemo o Walanda ini

mina naeta feilindo (tidak pernah damai karena mereka sudah tahu bahwa perilaku Belanda tidak bagus)

2. Rabuno Walanda pana timafugho (kelakuan Belanda tidak diampuni)
Kata karunggahino pada kalimat 1 bersinonim tidak komplit-tidak total dengan kariano pada kalimat 2 . Dikatakan sinonim tidak total-tidak komplit karena kedua kata ini selain tidak memiliki makna asosiatif yang sama juga tidak dapat saling mengganti dalam konteks kalimat yang sama. Untuk lebih jelasnya dapat

dilihat pada contoh kalimat di samping.

Kata delongko-longko pada kalimat 1 bersinonim tidak komplit-tidak total dengan delodo-lodo pada kalimat 2. Dikatakan sinonim tidak total-tidak komplit karena kedua kata ini selain tidak memiliki makna asosiatif yang sama juga tidak dapat saling mengganti dalam konteks kalimat yang sama. Untuk lebih jelasnya dapat dilihat pada contoh kalimat di samping.

Kata feilindo pada kalimat 1 bersinonim tidak komplit- tidak total dengan diundo pada kalimat 2 . Dikatakan sinonim tidak total-tidak komplit karena kedua kata ini selain tidak memiliki makna asosiatif yang sama juga tidak dapat saling mengganti dalam konteks kalimat yang sama. Untuk lebih jelasnya dapat dilihat pada contoh kalimat di samping.

Data pada tabel 5 di atas, menunjukkan bahwa dalam Bahasa Muna dialek Madongka terdapat jenis sinonim tidak total-tidak komplit

\subsection{Makna Sinonim dalam Bahasa Muna dialek Madongka}

Dari hasil analisis data, setiap jenis sinonim dalam Bahasa Muna dialek Madongka memeiliki makna leksikal, makna denotatif atau konseptual, dan makna kiasan. Makna tersebut dideskripsikan berikut ini.

\section{a. Makna Leksikal}

Makna leksikal yang dimaksud dalam penelitian ini adalah makna yang sesuai dengan referennya. Berdasarkan hasil analisis data percakapan, ditemukan kata-kata yang memiliki makna leksikal, yakni sebagai berikut:

1) Naoghae = naekahulei 'dia akan menangis'

Kata naoghae = naekahulei memiliki makna leksikal yakni peristiwa mengeluarkan air dari mata seseorang karena kesedihannya. 
2) Bheta = kawawe 'sarung'

Bheta = kawawe memiliki makna leksikal yakni suatu bahan tenunan yang biasanya digunakan oleh kaum laki-laki pada saat shalat.

3) Ondiwawa = ombahi 'menguap'

Ondiwawa = ombahi memiliki makna leksikal yakni peristiwa mengeluarkan angin dari mulut yang menandakan seseorang mengantuk.

4) Kansa-kansalo = noporawu 'campur'

Kansa-kansalo = noporawu memiliki makna leksikal yakni peristiwa memadukan dua jenis benda atau sifat sampai kedua jenis tersebut menyatu.

5) Meghompano = mebhatendeno 'yang melempar'

Kata meghompano $=$ mebhatendeno mengandung makna leksikal melakukan aktivitas melempar yakni memegang sebuah benda di tangannya kemudian melepaskannya di tempat lain dengan gerakan tangan siku dilipat kemudian benda tersebut dilepas baik kebelang, kesamping, ke bawah, maupun ke atas dengan menggunakan kekuatan.

6) Munta = nangku 'kunyah'

Munta = nangku mengandung makna leksikal yakni suatu proses menghaluskan makanan dengan gigi di dalam mulut.

7) Kambanuku = kakaililiku 'saya malu'

Kambanuku = kakaililiku mengandung makna leksikal yakni merasa sangat terganggu, tidak enak hati, merasa rendah karena melakukan sesuatu yang tidak wajar.

8) Tabhantolo = tafuma = tatangkahi ' kita makan'

Tabhantolo = tafuma $=$ tatangkahi mengandung makna leksikal yakni proses memasukkan makanan di dalam mulut yang kemudian di kunyah dan ditelan.

9) Tulumi = lalami 'membantu'

Tulumi = lalami mengandung makna leksikal yakni peristiwa menyumbangkan tenaga atau materi kepada orang lain.

10) Sabhangka = bhai 'teman/sahabat'

Sabhangka = bhai mengandung makna leksikal yakni seseorang yang paling dekat dengan kita selain keluarga di rumah.

11) Moperano $=$ momeluno 'yang nikmat'

Moperano $=$ momeluno mengandung makna leksikal yakni suatu nilai rasa yang unik yang terdapat pada makanan.

12) Heru = mbule 'cengeng'

Heru = mbule mengandung makna leksikal yakni suatu sifat yang sering menangis dan susah untuk dicari keinginannya. 


\section{b. Makna Denotatif atau Konseptual}

Makna denotatif menunjuk pada acuan tanpa diartikan secara luas. Berdasarkan hasil analisis data percakapan, ditemukan kata-kata yang memiliki makna denotatif atau konseptual, yakni sebagai berikut:

1) Nopogaa = noporunsa 'berpisah'

Kata nopogaa $=$ noporunsa mengandung makna denotatif yang maknanya adalah merujuk pada sesuatu perpisahan, perceraian, dan tidak saling bersama atau tidak saling berdampingan dengan seseorang atau sesuatu benda yang dia sukai.

2) Asumandu = asumiki 'saya sendokkan'

Asumandu = asumiki mengandung makna denotatif karena maknanya merujuk pada seseorang yang akan meyendok makanan untuk diberikan kepada orang lain

3) Kabisaraghomu

Kapogaughomu = mewamba-wamba 'yang kamu bicarakan' Kabisaraghomu = kapogaughomu = mewamba- $w a m b a$ mengandung makna denotatif karena maknanya merujuk pada sesuatu yang diungkapkan.

4) Tanowolom = tanokawum ' habis'

Tanowolom = tanokawum mengandung makna denotatif karena maknanya merujuk pada barang yang habis, ludes terpakai

5) Dorakoemo = dopunduemo 'ditangkap'

Dorakoemo = dopunduemo mengandung makna denotatif karena maknanya merujuk pada orang atau bisa binatang yang ditangkap karena kesalahan atau binatang karena untuk dijual.

6) Bha-bhaano = tandahano 'mula-mula'

Bha-bhaano = tandahano mengandung makna denotatif karena merujuk pada proses mengawali sesuatu yang ingin dikerjakan.

\section{c. Makna Kiasan}

Makna kiasan yakni makna yang sudah tergeser dari makna sebenarnya. Kata- kata bersinonim yang memiliki makna konseptual atau denotatif dapat dilihat seperti contoh di bawah ini:

1) Delongko-longko = delodo-lodo' 'tidur-tiduran'

Kata delingko-longko = delodo-lodo memiliki makna kiasan manusia pemalas yang hanya tidur-tiduran.

2) Mieno lambuno dan tungguno karete 'orang rumahnya/penjaga rumahnya'

Kata mieno lambuno dan tungguno karete memiliki makna suami yang bertugas sebagai penjaga rumah yang ditempati keluarganya, atau lebih tepatnya kepala rumah tangga. 


\section{Pembahasan}

Berdasarkan hasil analisis data diperoleh sinonim dalam bahsa Muna. Jenis sinonim yang terdapat dalam Bahasa Muna dialek Madongka ialah sinonim totalkomplit, sinonim komplit-tidak total, sinonim total-tidak sempurna, sinonim tidak total-tidak komplit.

Sinonim total-komplit, misalnya ndiwawa $=$ mbahi. Kedua kata ini dikatakan total-komplit karena memiliki hubungan asosiatif dan dapat saling bertukar tempat di dalam kalimat seperti tercantum dalam contoh kalimat (tabel 2) pada hasil penelitian. Untuk lebih jelasnya lagi dapat dilihat pada contoh berikut:

1. kangkondiwawam ingka maho owanu (seringnya kamu menguap padahal baru bangun)

2. kangkombahim ingka maho owanu (seringnya kamu menguap padahal baru bangun) kedua kata tersebut dapat saling menukar tempat dalam satu kalimat.

Sinonim komplit-tidak total, misalnya munta = nangku. Kedua kata ini dikatakan komplit-tidak total karena memiliki hubungan asosiatif namun tidak dapat saling bertukar tempat di dalam kalimat seperti tercantum dalam contoh kalimat (tabel 3) pada hasil penelitian. Untuk lebih jelasnya lagi dapat dilihat pada contoh berikut:

1. Munta fekamalu baita nolea taghimu (kunyah sampai halus jangan sampai sakit perutmu)

2. Kafembulaku we karete nokawue nonangkue sapi (tanamanku di halaman habis di kunyah/dimakan sapi)

Sinonim total-tidak sempurna, misalnya nopogaa dan noporunsa. Kedua kata ini dikatakan total-tidak sempurna karena tidak memiliki hubungan asosiatif namun bisa saling mengganti dalam kalimat yang sama seperti tercantum dalam contoh kalimat (tabel 4) pada hasil penelitian. Untuk lebih jelasnya lagi dapat dilihat pada contoh berikut.

1. Ama bhe ina Wa Ami doporunsamu rampano ama Wa Ami sakalo-kalowu (ayah dan ibunya Wa Ani sudah berpisah karena ayahnya Wa Ani mabukmabukan).

2. Ama bhe ina Wa Ami dopogaam rampano ama Wa Ami sakalo-kalowu (ayah dan ibunya Wa Ani sudah berpisah karena ayahnya Wa Ani mabuk-mabukan). Sinonim tidak total-tidak komplit, misalnya delodo-lodo = delongko-lonngko.

Kedua kata ini dikatakan tidak total-tidak komplit karena tidak memiliki hubungan asosiatif dan tidak dapat saling bertukar tempat di dalam kalimat seperti tercantum dalam contoh kalimat (tabel 5) pada hasil penelitian. Untuk lebih jelasnya lagi dapat dilihat pada contoh berikut.

1. Kala megau koem tao melodo-lodo kawu (pergi memasak jangan hanya tidurtiduran saja)

2. bheka awatu nelongko-longko kansuru w wawa, nosaki hadae. (kucing sana tidur-tiduran terus di bawah kolong rumah, mungkin dia sakit)

Persamaan sinonim bahasa Indonesia dan Bahasa Muna terletak pada Sinonim yang memiliki identitas makna konseptual dan asosiatif yang sama dan 
saling bertukar dalam semua konteks dan memiliki identitas makna konseptual dan asosiatif yang sama tetapi tidak dapat saling mengganti dalam konteks kalimat yang sama. Adapun berbedaan sinonim bahasa Indonesia dan Bahasa Muna yakni identitas makna konseptual dan asosiatif yang sama tetapi bisa saling mengganti dalam konteks kalimat yang lain, dan maknanya kurang lebih sama dengan makna ungkapan lain dari bahasa Indonesia dan Bahasa Muna.

Dialek Madongka Kecamatan Lakudo merupakan ungkapan (bisa berupa kata, frase, atau kalimat) yang maknanya kurang lebih sama dengan makna ungkapan lain yang sering digunakan dalam kehidupan sehari-hari dan juga dalam lingkup pendidikan, hal ini adanya beberapa faktor yang terdapat dalam suatu masyarakat antara lain: usia, pendidikan, agama, bidang kegiatan, profesi, dan latar belakang budaya daerah, maka bahasa itu menjadi beragam. Terjadinya kesinoniman Dialek Madongka dan Bahasa Indonesia sering digabungkan dalam percakapan dilingkup pendidikan, misalnya kalimat yang diawali dengan jenis penggunaan sinonim dalam kalimat yang ada dalam percakapan. Dengan adanya pembagian jenis sinonim dalam kalimat tersebut, maka dapat ditentukan maknanya dalam suatu kalimat yang terdapat dalam data percakapan informan dan teks Bahasa Muna. Adapun bahasa Muna seringkali digunakan pada ranah pendidikan, sedangkan bahasa Indonesia digunakan pada acara-acara resmi saja. Faktor kebiasaan penutur menggunakan bahasa Muna tersebut dalam dunia Pendidikan merupakan penyebab terjadinya interferensi bahasa Muna terhadap bahasa Indonesia.

\section{Kesimpulan}

Dari hasil analisis dan pembahasan di atas peneliti dapat menyimpulkan bahwa terdapat empat jenis sinonim dalam dialek bahasa tersebut yaitu, sinonim total - tidak sempurna, sinonim total - komplet, sinonim komplit - tidak total, dan sinonim total - tidak sempurna. Dan makna yang terdapat dalam sinonim bahasa Muna dialek Madongka yaitu, makna kiasan, konseptual dan leksikal.

Dengan adanya pembagian jenis sinonim dalam kalimat tersebut, maka dapat ditentukan maknanya dalam suatu kalimat yang terdapat dalam data percakapan informan berupa lisan.

1. Sinonim total-komplit, misalnya ndiwawa $=$ mbahi. Kedua kata ini dikatakan total-komplit karena memiliki hubungan asosiatif dan dapat saling bertukar tempat di dalam kalimat.

2. Sinonim komplit-tidak total, misalnya munta = nangku. Kedua kata ini dikatakan komplit-tidak total karena memiliki hubungan asosiatif namun tidak dapat saling bertukar tempat di dalam kalimat.

3. Sinonim total-tidak sempurna, misalnya nopogaa dan noporunsa. Kedua kata ini dikatakan total-tidak sempurna karena tidak memiliki hubungan asosiatif namun bisa saling mengganti dalam kalimat yang sama.

4. Sinonim tidak total-tidak komplit, misalnya delodo-lodo = delongko-lonngko. Kedua kata ini dikatakan tidak total-tidak komplit karena tidak memiliki hubungan asosiatif dan tidak dapat saling bertukar tempat di dalam kalimat. 


\section{Daftar Pustaka}

Marafat, L. O. S. (2017). Peran Semantis Pronomina Persona Bahasa Muna. RETORIKA: Jurnal IImu Bahasa, 1(1), 185. https://doi.org/10.22225/jr.1.1.23.185-200

Muniah, Hari Sulastri, dan Atidjah Hamid. 2010. Tata Bahasa Baku Bahasa Indonesia. Jakarta: Balai Pustaka.

Narbuko dan Achmadi. 2003. Metode Linguistik I: Ke Arah Memahami Metode Linguistik. Yogyakarta: Gajah Mada University Press

Palmer, F. R. 2011. Semantics. London: Cambridge University Press.

Pateda, Mansur. 2011. Semantik Leksikal. Gorontalo: Viladan.

Poedjosoedarmo, Gloria. 2007. Teori Semantik. Jakarta: Erlangga.

Rahardi. 2010. Sistem Kesinoniman dalam Bahasa Jawa. Jakarta: Departemen Pendidikan dan Kebudayaan.

Resmini, N. (2010). Hakikat dan Fungsi Bahasa Indonesia. Jurnal UPI, 1-44.

Tahir, D., Rahman, F., Rahman, A., Pattu, M. Amir. (2021). Kajian Verba Resiprokal Dalam Naskah Boegineesche Chrestomathie: Kajian Verba Resiprokal Dalam Naskah Boegineesche Chrestomathie. Fakultas IImu Budaya Universitas Hasanuddin.

Sholihah, R. A. (2018). Kontak Bahasa: Kedwibahasaan, Alih Kode, Campur Kode, Interferensi, Dan Integrasi. The 3rd Annual International Conference on Islamic Education, 361-376.

Sutiman dan Ririen Ekoyanantiasih. 2007. Kesinoniman Nomina Noninsani dalam Bahasa Indonesia. Jakarta: Pusat Bahasa Departemen Pendidikan Nasional.

Zaim, M. (2014). Metode Penelitian Bahasa: Pendekatan Struktural. Metode Penelitian Bahasa: Pendekatan Struktural, 1-123. http://repository.unp.ac.id/id/eprint/1830 